\title{
When COVID-19 meets centralized, personalized
}

\section{power}

\author{
The debate over whether autocracies or democracies are better at fighting epidemics is misguided. Under \\ President Xi Jinping's centralized command, his administration has both succeeded and failed at handling the \\ COVID-19 crisis. While it effectively curbed infections within China after the virus had spread, it failed to stem the \\ outbreak before it went global.
}

\section{Yuen Yuen Ang}

A s COVID-19 swells into a pandemic, a political debate is simultaneously raging about whether autocracies or democracies are better at fighting epidemics. In fact, this is a misplaced debate. In the current contentious geopolitical climate, popular narratives either condemn the Chinese leadership for its failures or hail its successes in dealing with COVID-19. For a balanced perspective, we must know when and how this regime failed and succeeded at responding to the virus since it first surfaced in Wuhan.

In China, the government under President Xi Jinping has displayed both strengths and lethal shortcomings in handling COVID-19. On the one hand, it successfully mobilized a strong national response once the paramount leader gave the green light to act. On the other hand, its lack of transparency and Xi's initial inaction delayed decisive measures to curb the outbreak before it spread across China and globally. Xi's centralized, personalized power has amplified both the strengths and failings of authoritarianism.

Strong authoritarian regimes excel at mass mobilization, but to prevent epidemics from arising in the first place, a government requires 'democratic characteristics' - that is, a climate that empowers not only civil society but also public officials to speak candidly about problems without fear of reprisals ${ }^{1}$. Conversely, having a democracy by itself is no guarantee of efficacy; it must also be combined with wise leadership and state capacity.

\section{Chairman of Everything}

Not all authoritarian regimes are alike, just as not all democracies are alike. Since its founding in 1949, China has consistently been a dictatorship, but it has undergone several types of dictatorships. Under Mao, China was a personalist dictatorship, where power was concentrated in one man at the helm. When Deng Xiaoping took over in the late 1970s, he dissolved Mao's personality cult and established a party-based dictatorship, operating on the norms of collective leadership, decentralized authority and pragmatism.

Xi Jinping's Presidency, which began in 2012, marks a sharp break from Deng-era traditions $s^{2,3}$. Upon taking office, he sidelined the Premier and other top leaders, installed his favourites, crowned himself as the 'Core Leader', enshrined 'Xi Jinping Thought' into the Constitution and abolished term limits. Within 2 years, his consolidation of personal power was so complete that many described him as 'the Chairman of Everything'

\section{Tightened up and stressed out}

On top of concentrating power, Xi's administration clamped down on civil society. In the decade before $\mathrm{Xi}$, China saw an encouraging expansion of political freedoms, muckraking journalism, transparency and public deliberation initiatives ${ }^{5}$. But starting in 2012, liberalizing reforms were rolled back while censorship and political control increased. This has impaired civil society's ability to detect and sound the alarm on problems.

In addition, China's vast bureaucratic apparatus also experienced tightened controls. In 2012, Mr Xi launched the most far-reaching crackdown on corruption in his Party's history. Rather than rely on transparency and disclosure of assets, he employed the strong arm of the Party apparatus, sending out an army of disciplinary inspectors to investigate and arrest corrupt officials. This campaign has subjected more than 1.5 million officials to disciplinary actions, including an unprecedented number of high-ranked officials 6 .

To his credit, Xi took on a brewing crisis of corruption that previous leaders had swept under the rug. But his campaign extended from policing graft to ensuring correct political thinking and conformity to Xi's orders. As Xinhua, the state press, declared on 26 November 2018, disciplinary authorities "should [...] closely follow the CPC [Communist Party of China] Central Committee with Comrade Xi Jinping at the core in terms of thinking, political orientation and actions" (http:// www.xinhuanet.com/english/201811/26/c_137632863.htm). In a bid to enforce communist ethos, his administration also required officials to intensively study Marxism and Xi Jinping Thought, including on a mobile app, and to engage in 'selfcriticisms. These practices all recall the Maoist era.

Under this climate, Chinese officials became afraid to take initiative or risks. This soon crystalized into an institutional problem-inaction and paralysis-also known in Chinese as 'lazy governance. It grew serious enough that the State Council warned against it by publicly shaming individual offenders for dereliction of duty, delaying decisions and leaving funds unused. With this backdrop in mind, we can better appreciate the turn of events within the Chinese government leading up to a pandemic, as summarized in Table 1.

\section{Passing the buck}

To be sure, governmental "inaction, denial and deception" in the face of novel viruses is a persistent feature of Chinese authoritarian governance, to quote global public health expert Yanzhong Huang ${ }^{7}$. These problems earlier manifested during the SARS outbreak in 2003. In this respect, Huang concluded, Beijing's response to epidemics "has not changed at all."

Yet although cover-ups occurred both during SARS and COVID-19, there are some striking differences in political and bureaucratic dynamics between the two crises. During SARS, delays and inaction resulted from "a fragmented bureaucracy and an oligarchic political structure," ${ }^{8}$ as Huang reported. SARS first emerged in Guangdong province in November 2002, but news only reached the Ministry of Health in Beijing in January 2003. 


\section{Table 1 | Highlights of key events in COVID-19}

Date Event

12 December 2019 First case of the virus was detected in Wuhan.

30 December 2019 Li Wenliang and several other medical personnel warned others about a SARS-like virus.

31 December 2019 China reported instances of an unknown virus to the WHO.

3 January $2020 \quad$ Local police made Dr Li sign an apology letter for spreading rumours.

7 January 2020 Chinese authorities confirmed that the virus is a novel coronavirus. The WHO named it 2019-nCoV.

7 January 2020 President $\mathrm{Xi}$ reported that on this day, "I gave instructions on controlling the outbreak."

13 January 2020 WHO reported first case of virus outside of China, in Thailand.

18 January 2020 Unaware of an outbreak, Wuhan residents held a banquet for 10,000 families.

19 January 2020 Beijing sends epidemiologists to Wuhan.

19 January 2020 Dr Zhong Nanshan, a respected veteran who fought SARS, announced that the virus is transmissible between people.

21 January 2020 The People's Daily mentioned the epidemic for the first time.

22 January 2020 Xi said that, on this day, "I explicitly ordered Hubei province to stop the flow of people outward."

23 January 2020 Wuhan was placed on partial lockdown. Flights and transport in and out of the city were suspended.

27 January 2020 Wuhan's mayor gave a livestreamed interview on CCTV, indicating that he was not authorized to publicize the outbreak.

28 January 2020 During his meeting with the director-general of the WHO, Xi said, "I am personally directing control efforts." Then he disappeared from public view for 6 days.

3 February 2020 Xi delivered an internal speech to the Politburo Standing Committee, detailing his actions since 7 January.

5 February $2020 \quad$ Xi reappeared in public view for a diplomatic meeting.

7 February 2020 Whistle-blower Dr Li died from the virus, unleashing a firestorm of outrage among Chinese netizens.

13 February 2020 Beijing removed and replaced Hubei's provincial party chief and Wuhan's city party chief.

15 February 2020 The Party magazine Qiushi published Xi's internal speech on 3 February.

1 March $2020 \quad$ Regulators imposed stringent new rules on Internet content in an already-controlled cyberspace.

11 March 2020

WHO declares COVID-19 a global pandemic.

Source: Total confirmed cases are reported by the WHO, starting on 22 January 2020, at https://covid.ourworldindata.org/data/ total_cases.csv.

The Ministry of Health informed the provincial health bureaus and then the State Council before it finally seized the attention of the Party's Politburo Standing Committee, China's highest ruling body, on 17 April. Reacting with 'a new level of candour', this committee demanded each province to accurately report the number of cases on a daily basis.

By contrast, during COVID-19, the timeline of communication appears more
Total confirmed

cases worldwide

-
-
-
-
-

\section{infor} informing the public before the lockdown. That this interview was livestreamed meant his words could not be censored.

While it is not uncommon for the central government to blame local authorities for cover-ups, this was the first time that a local official passed the buck to the top on live television. Zhou's risky self-defence appeared to work. As I write, he remains the mayor, while his higher-ranked colleague, Wuhan's party chief Ma Guoliang, was removed. By contrast, during SARS, it was Beijing's mayor who was sacked for mishandling the crisis. 


\section{From inaction to mass mobilization}

The concentration of power under Xi meant that the paramount leader played the role of a giant 'on-off' switch in the political system. Without authorization from the helm, as the Wuhan mayor revealed, local authorities did not dare publicize the outbreak. Every day of delay was costly. One study found the lockdown in Wuhan was too late in slowing the virus' spread because it had already reached multiple Chinese cities?.

Yet as soon as Xi gave a clear edict to act, no effort was spared. The entire bureaucracy suddenly jolted into action, erecting new hospitals within days and keeping hundreds of millions penned indoors since 23 January, making this the largest quarantine in human history. Fortunately, these forceful actions quickly brought down infection rates in China, which reported no new cases on 19 March (https://www.cnn.com/2020/03/19/ asia/coronavirus-covid-19-update-chinaintl-hnk/index.html).

\section{Conclusions}

Amid deep global anxiety, narratives about the COVID-19 pandemic are becoming politicized and reduced to over-simplistic memes. Readers should keep three points in mind.

First, Xi's administration failed to take decisive measures to contain COVID-19 early on, but it later succeeded in curbing it. Recently, Beijing has launched a global campaign to market China's success at controlling the outbreak, but it omits mention of the lethal shortcomings of centralized control: when local officials are afraid to report problems and civil society is suppressed, diseases fail to be detected and contained before they spread.

Second, while the Trump administration harshly blames China for its failings, it too has failed miserably. The President downplayed the risks of COVID-19 and did not prepare for an outbreak, despite abundant warnings from scientific experts. Worse, by calling COVID-19 the 'Chinese virus', Mr Trump's words incite racism and inadvertently helps Xi by inducing Chinese citizens to rally behind him. People in China have suffered and still suffer massively from this epidemic. Leaders rather than citizens should be held accountable. 'Xi's administration' must be distinguished from the nation of China.

Third, democracies vary widely in their ability to cope. While the government in the United States did not even prepare test kits before an explosion of infections, governments in Taiwan and South Korea harnessed a combination of extensive testing, self-isolation and transparency to quickly curb infections while minimizing economic disruptions. Democracies can be effective at responding to epidemics, provided that they have wise leadership and administrative capacity to implement solutions.

Yuen Yuen Ang (D)

University of Michigan, Ann Arbor, Ann Arbor, MI, USA.

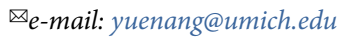

Published online: 9 April 2020

https://doi.org/10.1038/s41562-020-0872-3

\section{References}

1. Ang, Y. Autocracy with Chinese characteristics: Beijing's behind the scenes reforms. Foreign Affairs May/June 2018, 39-46 (2018)

2. Minzer, C. End of an Era: China's Authoritarian Revival (Oxford Univ. Press, 2018)

3. Economy, E. The Third Revolution: Xi Jinping and the New Chinese State (Oxford Univ. Press, 2018).

4. Allison, G. The Chairman of Everything: why Chinese president $\mathrm{Xi}$ Jinping will change history. New Statesman https://www. newstatesman.com/world/asia/2017/12/chairman-everythingwhy-chinese-president-xi-jinping-will-change-history (4 December 2017).

5. Stromseth, J., Malesky, E. \& Gueorguiev, D. China’s Governance Puzzle: Enabling Transparency and Participation in a Single-Party State (Cambridge Univ. Press, 2017).

6. Ang. Y. China's Gilded Age: The Paradox of Economic Growth and Vast Corruption (Cambridge Univ. Press, 2020).

7. Huang, Y. Is China setting up itself for another epidemic? The New York Times https://www.nytimes.com/2020/01/23/ opinion/coronavirus-china-wuhan.html (23 January 2020).

8. Huang, Y. The SARS epidemic and its aftermath in China: a political perspective. in Learning from SARS: Preparing for the next disease outbreak (Knobler, S., et al., eds) 116-136 (National Academics Press, 2004)

9. Wu, J., Leung, K. \& Leung, G. Lancet 395, 689-697 (2020).

\section{Competing interests}

The author declares no competing interests. 